\title{
TRADE-OFF THEORY VERSUS PECKING ORDER THEORY: CAPITAL STRUCTURE DECISIONS IN A PERIPHERAL REGION OF PORTUGAL
}

\author{
Zélia SERRASQUEIRO ${ }^{1}$, Ana CAETANO \\ 1,2Department of Management and Economics, Faculty of Social and Human Sciences, \\ University of Beira Interior, Covilhã, 6200-209, Portugal \\ CEFAGE Research Center - University of Évora, Évora 7000-809, Portugal \\ E-mails:12elia@ubi.pt (correspondingauthor); ${ }^{2}$ anacaetano19@gmail.com
}

Received 19 December 2011; accepted 16 October 2012

\begin{abstract}
This paper seeks to analyse whether the capital structure decisions of Small and Medium-Sized Enterprises (SMEs) are closer to the assumptions of Trade-Off Theory or to those of Pecking Order Theory. We use a sample of SMEs located in the interior region of Portugal, using the LSDVC dynamic estimator as method of estimation, the empirical evidence obtained allows us to conclude that the most profitable and oldest SMEs resort less to debt, which corroborates the forecasts of Pecking Order Theory. SMEs, with greater size, resort more to debt, corroborating the forecasts of Trade-Off Theory and Pecking Order Theory. In addition, SMEs adjust noticeably their current level of debt towards the optimal debt ratio, which corroborates what is forecast by Trade-Off Theory. Therefore, this paper enhances that Trade-Off and Pecking Order Theories are not mutually exclusive in explaining the capital structure decisions of SMEs. The results suggest that younger and smaller SMEs should be object of public financing support, when the internal financing is clearly insufficient to fund those firms' activities.
\end{abstract}

Keywords: Beira Interior, capital structure, Pecking Order Theory, SMEs, Trade-Off Theory, financing support.

JEL Classification: C23, G32, L26, M10, M20.

\section{Introduction}

The studies by Modigliani and Miller $(1958,1963)$ generated an extensive discussion about firm's capital structure, with new theories developing, namely Agency Theory, Signalling Theory, Trade-Off Theory and Pecking Order Theory. Despite the various studies carried out seeking to explain this subject, there is no consensus about the theory that best explains the small and medium-sized enterprises (SMEs) capital structure decisions. 
According to Trade-Off theory (Kraus, Lintzenberger 1973; Scott 1977; Kim 1978), firms should reach the level of debt that maximizes the advantages of debt tax-shields and minimizes the possibility of bankruptcy. Agency theory (Jensen, Meckling 1976) shows how conflicts existing, on the one hand, between managers and owners and, on the other, between owners-managers and creditors, can affect firms' financing decisions. Ross (1977) developed Signalling theory that, in the presence of information asymmetry, approaches the possibility of owners-managers that are better-informed to send out signs to external investors through firm's capital structure decisions.

Pecking Order Theory (Myers 1984; Myers, Majluf 1984), states that firms have not a defined capital structure. In this context, the firms' capital structure is the result of hierarchical financing decisions over time (Shyam-Sunder, Myers 1999).

Trade-Off and Pecking Order Theories have often been placed in opposition, seeking to identify which of them offers the best explanation regarding capital structure decisions. A large number of empirical studies have studied the debt determinants of large and listed companies. Only more recently, several empirical studies (Van der Wijst, Thurik 1993; Chittenden et al. 1996; Jordan et al. 1998; Michaelas et al. 1999; Sogorb-Mira 2005) have analysed SME capital structure decisions.

The problems of adverse selection are more severe to small and medium-sized companies, since the majority of them are not listed on the Stock Exchange, resulting in a greater degree of uncertainty, concerning the information publicly available about those firms (McMahon et al. 1993).

The lack of capital, via access to debt, is considerably relevant in SME, a consequence of asymmetric information problems. Thereby, the understanding of the determinants of capital structure is important to allow the application of correct measures to encourage the availability of capital to SME, consequently stimulating the growth and development of these firms.

The studies by Van der Wijst and Thurik (1993), Chittenden et al. (1996), Jordan et al. (1998), and Michaelas et al. (1999) analyse the capital structure of small and mediumsized companies in a static perspective. More recently, based on the significant advance of econometric techniques, the studies by Shyam-Sunder and Myers (1999), De Miguel and Pindado (2001), Hovakimian et al. (2001), Ozkan (2001), Fama and French (2002), analyse capital structure decisions in a dynamic way. As Scherr and Hulburt (2001) state, trying to understand the dynamism of capital structure in SME is fundamental, given that these companies must carry out frequent adjustments toward the target debt level, as a consequence of the need to renegotiate the level and terms of debt.

Therefore, the objectives of this study are to: i) analyse if Trade-Off and Pecking Order Theories, seeking to which of them offers the best explanation regarding SME capital structure decisions; and ii) analyse if SMEs carry out adjustments toward their target level of debt.

With this study, we seek to contribute to extending the study of SME capital structure, considering SMEs in the interior region of Portugal. Regional disparities in terms of 
economic growth and economic development are a real problem in economy. In this context, conclude that the firms' activity may be a particular importance to economic growth and economic development o regions.

It is important to analyse the financing decisions of SMEs located in an interior and less developed region of Portugal, looking for results that may be extended to the context of countries or regions with particular rates of development. In particular, the current study seeks to analyse if financing decisions are influenced by a financing strategy resulting from the balance between debt tax shields and bankruptcy costs associated with debt, or from a hierarchical order of selection of financing sources, which can be explained by the existence of information asymmetry, and by the costs of different sources of finance. In this context, the current study seeks to analyse if SME financing behaviour agrees with the forecasts of Pecking Order Theory or with those of Trade-Off Theory. To reach the main objective of this study, we consider a sample of 53 SMEs for the period between 1998 and 2005. As method of estimation, we use panel data models, namely the LSDVC (2005) dynamic estimator. The results obtained show the existence of negative relationships between profitability and debt, and between age and debt, suggesting that SMEs follow the Pecking Order Theory in their capital structure decisions. Furthermore, it was identified a positive relationship between size and debt, which can also be interpreted in accordance with the assumptions of Pecking Order Theory. Also, the results indicate that SMEs adjust, relatively quickly, their actual debt ratio towards the optimal debt ratio. This result suggests that the costs of financial imbalance are greater than the costs of the adjustment of the actual debt ratio towards the optimal debt ratio. Here, SMEs appear to adopt a financing behaviour in agreement with the forecasts of TradeOff Theory. In general, the results suggest that Pecking Order and Trade-Off Theories are not mutually exclusive in explaining the capital structure decisions of SMEs

After this introduction, this study is structured as follows: Section one gives a review of the literature on Trade-Off and Pecking Order Theories; Section two presents the methodology; Section three presents and discusses the results obtained; and finally, the last Section presents conclusions, limitations and suggestions for future research.

\section{SMEs' capital structure decisions and research hypotheses}

\subsection{SMEs' capital structure decisions in the context of Pecking Order and Trade-Off Theories}

The main pillar of the Pecking Order Theory is the information asymmetry, and so SMEs that face problems of asymmetric information and higher costs of external equity may adopt a financing strategy close to the forecasts of that theory (Ibbotson et al. 2001). Various empirical studies (Chittenden et al. 1996; Michaelas et al. 1999; Berggren et al. 2000; López-Gracia, Aybar-Arias 2000; Sogorb-Mira 2005; Ou, Haynes 2006; Ramalho, Silva 2009) support the Pecking Order Theory in explaining SME capital structure decisions. However, López-Gracia and Sogorb-Mira (2008) and González and González (2012) conclude that Pecking Order Theory and Trade-Off Theory are 
not mutually exclusive, i.e., when SMEs adopt a financing behaviour following one theory does not imply a distance from the other theory. Chittenden et al. (1996), in their study of SMEs in the United Kingdom, found empirical evidence that corroborates the existence of a hierarchy of preference in SME choice of financing sources. Michaelas et al. (1999) conclude that, in general, the owners/managers of British SMEs tend to retain profits, and, only, resort to debt after internal financing is exhausted. This firms' financing behaviour is in agreement with Pecking Order Theory. Sogorb-Mira (2001) concluded that both Trade-Off and Pecking Order Theories appear to explain Spanish SME capital structure decisions, with the results being more statistically significant regarding Pecking Order Theory. It was found that Pecking Order Theory seems to explain relatively well the capital structure decisions of SME, although the justification underlying that theory may be associated with the fact that SME owners are reluctant to use external financing due to their fear of losing the firm's control. Sogorb-Mira (2005) concluded that Pecking Order Theory seems to explain relatively well the financing behaviour followed by SMEs. Nevertheless, the author refers that conclusion may be a consequence of the fact that SME owners are, usually, very reluctant to open firm's equity to external investors to avoid the loss of firm's control and management. LopézGracia and Sogorb-Mira (2008) concluded that Trade-Off Theory and Pecking Order Theory appear to explain the financing behaviour of Spanish SMEs, although greater consistency was found in the results referring to Trade-Off Theory. In this context, the results of empirical studies suggest that Pecking Order and Trade-Off Theories are not mutually exclusive in explaining SMEs' capital structure decisions.

\subsection{Trade-Off Theory - research hypotheses}

Trade-Off Theory claims that firms have an incentive to use debt to benefit from debt tax-shields. So it can be stated that a firm has an incentive to turn to debt as the generation of annual profits allows benefiting from the debt tax shields. According to several studies (DeAngelo, Masulis 1980; Haugen, Senbet 1986; Fama, French 2002; LópezGracia, Sogorb-Mira 2008), a positive relationship is expected between the effective tax rate and debt. On the basis of this argument, the first hypothesis is formulated in the context of Trade-Off Theory:

H1: There is a positive relationship between the effective tax rate and debt in SMEs.

According to DeAngelo and Masulis (1980), non-debt tax shields, such as deductions allowed by amortizations and investment tax credit could substitute the role of tax savings permitted by debt. This implies that a firm with a high level of non-debt tax shields will probably have a lower level of debt than a firm with low non-debt tax shields. The Trade-Off Theory forecasts a negative relationship between non-debt tax shields and debt, therefore it is formulated the following research hypothesis:

H2: There is a negative relationship between other non-debt tax shields and debt in SMEs.

According to the Trade-Off Theory, the most profitable firms have capacity for a higher level of debt, taking advantage of debt tax shields (Mackie-Mason 1990; Fama, French 2002). Highly profitable firms are likely more able to fulfil their responsibilities regard- 
ing the repayment of debt and interests, which contributes to a less likelihood of bankruptcy. DeAngelo and Masulis (1980) state that in the absence of non-debt tax shields, more profitable firms can take advantage of their greater profitability by increasing debt, and consequently increasing debt tax shields. The anterior arguments justify the possibility of a positive relationship between profitability and debt, and so the following hypothesis is formulated:

H3: There is a positive relationship between profitability and debt in SMEs.

Kim (1978) argues that use of debt, although promoting tax shields, increases the probability of firm bankruptcy, which may contribute to a reduction of growth opportunities in the future. Consequently, firms are more reluctant to use debt, so as not to see their future growth diminished. Myers (1984) states that as bankruptcy and agency costs are greater for firms with high expectations of growth opportunities, firms can be reluctant to use high amounts of debt so as not to increase their likelihood of bankruptcy. As a result, firms with high growth opportunities may not use debt as the first financing option. Therefore, in the Trade-Off Theory approach, a negative relationship is expected between debt and growth opportunities. According to the Trade-Off Theory, firms with greater growth opportunities have a lower level of debt, given that greater investment opportunities increase the possibility of agency problems between managers/owners and creditors, because the former have a great incentive to under-invest (Myers 1977; Smith, Warner 1979). Additionally, according to the Trade-Off approach, growth opportunities have no value in the case of firm bankruptcy, and so bankruptcy costs associated with recourse to debt are greater in firms with high growth opportunities. For these reasons, according to Trade-Off Theory, the relationship between growth opportunities and debt is negative. Based on these arguments, the following research hypothesis is formulated:

H4: There is a negative relationship between growth opportunities and debt in SMEs.

Tangible assets can be used as collateral in the case of firm bankruptcy, protecting the creditors' interests. Aside from solving problems of bankruptcy costs inherent in the use of debt, the tangible assets may also be used to lessen agency problems (Degryse et al. 2010). Michaelas et al. (1999) claim that firms, with valuable tangible assets that can be used as guarantees, have easier access to external finance, and they have probably higher levels of debt than firms with low levels of tangible assets. Therefore, in the Trade-Off approach, a positive relationship is forecast between asset tangibility and firms' level of debt, and so the following hypothesis is formulated:

H5: There is a positive relationship between tangibility of assets and debt in SMEs.

Larger firms tend to have greater diversification of activities that implies less likelihood of bankruptcy (Warner 1977; Ang et al. 1982; Titman, Wessels 1988). In addition, large firms with less volatile profits are more likely to take advantage of the debt tax shields, so increasing the potential benefits of debt (Smith, Stulz 1985).

Therefore, according to the Trade-Off approach, large firms tend to increase their level of debt as a consequence of the lesser likelihood of bankruptcy, and also as a way to increase the debt tax shields. Therefore a positive relationship is expected between size and debt, as defined in the following hypothesis: 
H6: There is a positive relationship between size and debt in SMEs.

We can argue that age can be an important determinant of capital structure decisions, given that the firms in the later stages of their life-cycle have more advantageous terms in obtaining debt than young firms. According to Ramalho and Silva (2009), the older is the firm (and the greater is its reputation), the lower is the cost of debt, as long as creditors believe that the firm will not undertake projects that imply the substitution of assets. From this, it can be concluded that the older is the firm, the greater is its reputation, which may imply lower agency problems, allowing easier access to debt. Therefore, a positive relationship is expected between age and debt, as formulated in the following research hypothesis:

H7: There is a positive relationship between age and debt in SMEs.

According to Trade-Off Theory, SMEs are firms operating in markets, which are not very concentrated, therefore facing great competition (Ang 1991). As a result, they are subject to higher business risk, and greater probability of bankruptcy. Consequently, SMEs tend to reduce their level of debt. SMEs with a high level of business risk have a greater risk of bankruptcy, and so they should reduce their debt. According to Bradley et al. (1984), SMEs with volatile operational profits are very likely to go bankrupt, and, therefore find it difficult to obtain credit. Therefore, a negative relationship is expected between firms' level of risk and debt, as formulated in the following research hypothesis:

H8: There is a negative relationship between risk and debt in SMEs.

According to Trade-Off Theory, there is a debt ratio, which is the ratio where tax benefits are equal to the bankruptcy and agency costs associated with debt. Whenever firms deviate from their debt ratio, the existence of adjustment costs prevents firms from making a total adjustment to that ratio, and so Trade-Off Theory forecasts that firms make a partial adjustment of debt towards the optimal debt ratio (Lev, Peckelman 1975; Ang 1976; Taggart 1977; Jalilvand, Harris 1984; López-Gracia, Sogorb-Mira 2008). Adopting the perspective of Trade-Off Theory, the following research hypothesis is formulated:

H9: SMEs adjust their level of debt towards the optimal debt ratio.

\subsection{Pecking Order Theory - research hypotheses}

According to the Pecking Order Theory, firms may be financially constrained due to the information asymmetry between managers/owners and investors, and so firms adopt a hierarchy in selecting sources of finance. In the first place, firms use internal financing (retained profits); if it is necessary to turn to external financing, firms use debt with little or no risk, which usually corresponds to short-term debt; and in the last place, firms will select external equity. Therefore, highly profitable firms have a low debt ratio. The more profitable is the firm, the greater is its capacity to accumulate retained profits, and so there is less need to turn to external financing. A negative relationship is therefore expected between profitability and debt, in accordance with the Pecking Order approach, as identified in various studies (Sogorb-Mira 2005; Ramalho, Silva 2009; González, 
González 2012). On the basis of the anterior exposition, it is formulated the following hypothesis:

H10: There is a negative relationship between profitability and debt in SMEs.

In accordance with the Pecking Order Theory, firms with high growth opportunities must undertake major investment projects, which generate greater needs for finance. When internal financing is exhausted, firms prefer debt rather than external equity for funding growth opportunities, which are associated with a greater risk than do investment in assets in place (Baskin 1989; Shyam-Sunder, Myers 1999; Viviani 2008; Ramalho, Silva 2009). These authors state that firms with good growth opportunities increase debt when internal funds are insufficient. Therefore, Pecking Order Theory forecasts a positive relationship between growth opportunities and debt, and so we formulate the following research hypothesis:

H11: There is a positive relationship between growth opportunities and debt in SMEs.

Considering that a higher level of tangible assets increases the possibility of offering collaterals, lessening problems of information asymmetry between SME managers/ owners and creditors (Berger, Udell 1998; Michaelas et al. 1999; Sogorb-Mira 2005), a positive relationship is expected between asset tangibility and debt. According to the Pecking Order approach, we formulate the following research hypothesis:

H12: There is a positive relationship between asset tangibility and level of debt in SMEs.

Pecking Order Theory predicts that greater size allows a firm to accumulate retained earnings, and so less debt is necessary. Therefore, Pecking Order Theory predicts a negative relationship between size and debt (López-Gracia, Sogorb-Mira 2008). Ezeoha (2008) identify a negative relationship between firm size and debt, which is according to the assumptions of the Pecking Order Theory, therefore small firms should use less debt due to the costs of external financing originated by asymmetric information problems. However, according to Myers (1984), greater firm size lessens the problems of information asymmetry between managers/owners and creditors, allowing firms to obtain debt on more favourable terms. A positive relationship between size and debt may be expected in the Pecking Order approach that is verified in various studies (Marsh 1982; Wald 1999; Psillaki, Daskalakis 2009). According to Pecking Order Theory, the relationship between size and debt can be positive or negative, and so the following research hypothesis is formulated.

H13: There is a positive/negative relationship between size and debt in SMEs.

According to La Rocca et al. (2011), the Pecking Order Theory is a useful tool for the analysis of the financing behaviour of firms along the life cycle. According to Pecking Order Theory, older firms have a greater capacity to retain and accumulate earnings, and so the need to resort to external financing to solve their financing requirements will be less than in the case of younger SMEs. The likelihood of old SMEs to retain profits over time is considerable, so the older SMEs diminish the recourse to debt. Considering the above, the following hypothesis is formulated: 
H14: There is a negative relationship between age and debt in SMEs.

Table 1 presents the expected relationships between the dependent variable and the independent variables, according to Trade-Off Theory and Pecking Order Theory.

Table 1. Expected relationships between debt and determinants

\begin{tabular}{lcc}
\hline \multicolumn{1}{c}{ Determinants } & $\begin{array}{c}\text { Expected relationship }- \\
\text { Pecking Order Theory }\end{array}$ & $\begin{array}{c}\text { Expected relationship - } \\
\text { Trade-Off Theory }\end{array}$ \\
\hline Efective tax rate & - & Positive \\
\hline Non-debt tax shields & - & Negative \\
\hline Growth opportunities & Positive & Negative \\
\hline Tangible assets & Positive & Positive \\
\hline Profitability & Negative & Positive \\
\hline Size & Positive or negative & Positive \\
\hline Age & Negative & Positive \\
\hline Risk & - & Negative \\
\hline
\end{tabular}

\section{Methodology}

\subsection{Database}

The firms of the sample of this study are SMEs belonging to the interior region of Portugal, more precisely to the Beira Interior region. Data was gathered from the System Analysis of Iberian Balance Sheets database (SABI), supplied by Bureau van Dijk, for the period 1998 to 2005 . The SABI contains the balance sheets and income statements of Portuguese firms. Furthermore, the SABI database also contains other kind of data, namely the firm's age and the number of employees. In the database, firstly, we consider the non-financial firms geographically located in the district of Castelo Branco, belonging to Beira Interior region of Portugal. After that, we select the firms on the basis of the European Union recommendation L124/36 (2003/361/CE). According to this recommendation, a business unit is considered an SME when it meets two of the following criteria: i) fewer than 250 employees; ii) assets under 43 million Euros; iii) business turnover under 50 million Euros. After this process, we eliminate the SME without enough data available in the database for the period of analysis. For SME in the research sample, we collect data for the period 1998 to 2005. The data was introduced in the statistical package of STATA, and on the basis of the descriptive statistics we eliminate the SME identified as outliers. The final sample is composed by 53 SMEs with data collected for the period 1998 to 2005, obtaining a total of 371 observations.

\subsection{Variables}

The choice of variables and respective proxies was based on previous studies, such as Titman and Wessels (1988); Van der Wijst and Thurik (1993); Chittenden et al. (1996); Michaelas et al. (1999); Hall et al. (2000); De Miguel and Pindado (2001); Sogorb- 
Mira (2001, 2005); Cassar and Holmes (2003); Ramalho and Silva (2009); González and González (2012); Serrasqueiro and Maçãs Nunes (2012).

The following table presents the variables to be used in this study, together with their corresponding measures.

Table 2. Variables and measurement

\begin{tabular}{ll}
\hline \multicolumn{1}{c}{ Variables } & \multicolumn{1}{c}{ Measurement } \\
\hline Dependent variable & Ratio between total liabilities and total assets \\
\hline Debt $\left(\mathrm{LEV}_{i, t}\right)$ & \\
\hline Independent variables & $\begin{array}{l}\text { Ratio of income tax paid and profits before taxes } \\
\text { and after interest }\end{array}$ \\
\hline Effective tax rate (ETR) & Ratio between depreciations and total assets \\
\hline Non-debt tax shields (NDTS) & Ratio between intangible assets and total assets \\
\hline Growth opportunities (GO) & Ratio between fixed assets and total assets \\
\hline Assets tangibility (TANG) & $\begin{array}{l}\text { Ratio of operational results before interest and tax } \\
\text { to total assets }\end{array}$ \\
\hline Profitability (PROF) & \begin{tabular}{l} 
Logarithm to sales \\
\hline Size (SIZE)
\end{tabular} \\
\hline Age (AGE) & Logarithm of the number of years of firm in existence \\
\hline Risk (EVOL) & $\begin{array}{l}\text { Absolute value of percentage change of earnings before } \\
\text { interest, taxes and depreciations }\end{array}$ \\
\hline
\end{tabular}

\subsection{Estimation method}

According to Arellano and Bond (1991), use of dynamic panel estimators has the following advantages: i) control of endogeneity; ii) greater control of possible collinearity between independent variables; and iii) reduction of the problem of neglecting explanatory variables. In addition, use of dynamic estimators has the following advantages over static panel models: i) use of variables, in first differences, allows the elimination of the correlation between non-observable individual effects and the lagged dependent variable; and ii) use of instrumental variables (lagged dependent and independent variables) allows elimination of the correlation between the error and the lagged dependent variable, avoiding possible result bias, mainly, concerning the estimation of the relationship between the dependent variable in the current period and the dependent variable in the previous period.

As method of estimation we use the LSDVC (Least Squares Dummy Variable Corrected) estimator by Bruno (2005). This estimator is appropriate when the database is not very large, as is the case with the database used in this study. Use of the LSDVC (2005) dynamic estimator allows correction of the results estimated with the Arellano and Bond (1991), Blundell and Bond (1998), and Anderson and Hsiao (1981) dynamic estimators, lessening the effect of the database not very large. Indeed, use of the GMM, 
GMM system, Anderson and Hsiao dynamic estimators generates a set of instrumental variables that reduce considerably the degrees of freedom when databases are not very large, which may lead to bias in the estimated results. This problem is particularly relevant in the case of the GMM system estimator, given that a significant number of generated instrumental variables is implicit in the use of that estimator.

Asides from the above, when the dependent variable is persistent, i.e., when there is a strong correlation between debt in the present and previous periods, Blundell and Bond (1998) conclude that use of the GMM system estimator is clearly appropriate, avoiding bias in the estimated results. Firm's debt is associated with high persistency, with a high correlation between debt in the present and previous periods. This being so, use of the GMM system estimator is the most appropriate way to estimate the determinants of firm debt, rather than using the GMM and Anderson and Hsiao estimators. However, as mentioned above, use of the GMM system estimator by Blundell and Bond (1998) implies a considerable number of instrumental variables, and may lead to result bias when databases are not very large, as is the case here. Therefore, use of the LSDVC estimator by Bruno (2005) is considered to be suitable for the database used in this study, since it is an appropriate estimator, for correcting results obtained with other dynamic estimators, when databases are not very large. In this study, we choose to present the results obtained with the LSDVC (2005) estimator, for correction of the results obtained with the GMM, GMM system, Anderson and Hsiao estimators.

Since our objective is to estimate the adjustment of actual SME debt towards the optimal debt level, as well as the relationships between determinants and debt forecast by Trade-Off and Pecking Order Theories, we turn to the partial adjustment model, just as López-Gracia and Sánchez-Andújar (2007) and López-Gracia and Sogorb-Mira (2008). The partial adjustment model is given by:

$$
L e v_{i, t}-\operatorname{Lev}_{i, t-1}=\alpha\left(\operatorname{Lev}_{i, t} *-\operatorname{Lev}_{i, t-1}\right),
$$

where: $L e v_{i, t}$ is the debt of firm $i$ in the period $t ; \operatorname{Lev}_{i, t-1}$ is the debt of firm $i$ in the period $t-1 ; L e v_{i, t} *$ is the debt ratio of firm $i$ in period $t$ and $\alpha$ is the speed of adjustment of actual level of debt towards the optimal debt ratio.

To estimate the above equation it is necessary to determine the optimal debt ratio, which is not directly observable. There are different ways to calculate the optimal level of debt: i) considering the median of debt of the industry sector to which the firms belong; ii) considering the mean of the historical values of firms' debt; iii) considering the specific characteristics of the firms. However, on the one hand, considering the median of debt of the industry sector, it is not easy to justify why the level of debt is the same for all firms in the industry sector; on the other hand, considering the level of debt as the mean of debt of the anterior periods, it is also not easy to justify why the firm's optimal level of debt is constant over time (Jalilvand, Harris 1984; Shyam-Sunder, Myers 1999). Consequently, in the current study, as the majority of studies about capital structure decisions (e. g. López-Gracia, Sánchez-Andújar 2007; López-Gracia, SogorbMira 2008), we consider that the optimal level of debt depends on the firms' specific 
characteristics, and on the macroeconomic conditions (i.e. measured by annual dummy variables) as well as on the firms' unobservable specific characteristics (i.e. measured by $u_{i}$ ). Consequently, we avoid the situation of debt not being constant for different firms and/or for different periods, but assuring that debt varies for each firm and for each period, which is more admissible, in a theoretical perspective. Furthermore, it is worthwhile highlighting to refer that Shyam-Sunder and Myers (1999) obtained results that, regarding the adjustment of actual level of debt towards the optimal level of debt, and the relationships between determinants and debt, do not suffer considerable alterations as a function of the way of determination of the level of debt. On the basis of the anterior exposition, firms' optimal debt ratio is given by:

$$
\operatorname{Lev}_{i, t} *=\sum_{K=1}^{8} \varphi_{K} Z_{k, i, t}+d_{t}+u_{i}+v_{i, t},
$$

where: $Z_{K, i, t}$ is the determinant $k\left(\mathrm{ERT}_{i, t} ; \mathrm{NDTS}_{i, t}, \mathrm{PROF}_{i, t} ; \mathrm{GO}_{i, t} ; \mathrm{TANG}_{i, t} ; \mathrm{SIZE}_{i, t}\right.$; $\mathrm{AGE}_{i, t} ; \mathrm{EVOL}_{i, t}$ of the book value of the debt of firm $i$ at time $t, \varphi_{K}$ are the coefficients of each debt determinant, $d_{t}$ are the temporal dummy variables, $u_{i}$ are individual nonobservable effects, and $v_{i, t}$ is the error term.

Substituting (2) in (1) and regrouping the terms, we have:

$$
\operatorname{Lev}_{i, t}=\lambda_{0} \operatorname{Lev}_{i, t-1}+\sum_{K=1}^{8} \beta_{K} Z_{k, i, t}+\theta_{t}+\eta_{i}+\varepsilon_{i, t},
$$

where: $\lambda_{0}=(1-\alpha), \beta_{K}=\alpha \varphi_{K}, \theta_{t}=\alpha d_{t}, \eta_{i}=\alpha u_{i}$, and $\varepsilon_{i, t}=\alpha v_{i, t}$.

The lower the value of $\lambda_{0}$, the greater $\alpha$ will be, i.e., the greater the adjustment of actual SME debt towards the optimal debt ratio. The higher the value of $\lambda_{0}$, the lower $\alpha$ will be, i.e., the lower the adjustment of actual SME debt towards the optimal debt ratio.

\section{Results and discussions}

\subsection{Results}

The descriptive statistics of the sample considered in this study are presented in Table 3.

Analysis of the descriptive statistics (Table 3) suggests that the average debt of SMEs is 0.62148 . It is also of note that the debt of SMEs, considered in the sample, presents a minimum value of 0.02378 and reaches a maximum value of 0.97002 . These figures suggest that a considerable number of SMEs have debt as their main source of finance. We can also mention that on average firm size (calculated based on turnover) is approximately 525060 Euros, and that the average age of SMEs is approximately 17 years. The profitability of SMEs is low, with an average value of 0.04055 . We also conclude that the volatility of some variables is high, because for most of them the standard deviation is greater than the respective mean. More precisely, the variables effective tax rate, growth opportunities, profitability, and risk are found to present great volatility. As for the remaining variables like debt, non-debt tax shields, tangibility, size, and age, their standard deviation is under their respective means, which allows us to conclude that the volatility of these variables is not considerable. 
Table 3. Descriptive statistics

\begin{tabular}{lccccc}
\hline \multicolumn{1}{c}{ Variables } & Observations & Mean & Stand. dev. & Min & Max \\
\hline LEV $_{i, t}$ & 371 & 0.62148 & 0.20332 & 0.02378 & 0.97002 \\
\hline ETR $_{i, t}$ & 371 & 0.21108 & 0.71845 & -5.6569 & 5.75000 \\
\hline NDTS $_{i, t}$ & 371 & 0.04806 & 0.04107 & 0.00049 & 0.23570 \\
\hline GO $_{i, t}$ & 371 & 0.01098 & 0.02700 & 0 & 0.22285 \\
\hline TANG $_{i, t}$ & 371 & 0.27885 & 0.19385 & 0 & 0.84876 \\
\hline PROF $_{i, t}$ & 371 & 0.04055 & 0.06712 & -0.17639 & 0.37056 \\
\hline SIZE $_{i, t}$ & 371 & 6.26352 & 0.56041 & 4.07759 & 7.36607 \\
\hline EVOL $_{i, t}$ & 371 & 2.82730 & 0.69467 & 0 & 4.15888 \\
\hline
\end{tabular}

The Table A1 in Appendix presents the correlation matrix of the variables used in this study.

According to Gujarati and Porter (2010), when the correlation coefficients between independent variables are not above $50 \%$, the problem of collinearity between independent variables will not be particularly relevant. In this study, all correlations coefficients between independent variables are not above $50 \%$, and so the problem of collinearity between independent variables will not be particularly relevant in this study.

The following table presents the results obtained from application of the LSDVC dynamic estimator by Bruno (2005), to correct the results estimated with the GMM, GMM system, and Anderson and Hsiao dynamic estimators.

Regardless of considering application of the LSDVC dynamic estimator by Bruno (2005) to correct the results obtained with the GMM, GMM system, or Anderson and Hsiao dynamic estimators, the empirical evidence obtained allows us to conclude that: i) there is not a statistically significant relationship between effective tax rate and debt; ii) there is not a statistically significant relationship between non-debt tax shields and debt; iii) there is not a statistically significant relationship between growth opportunities and debt; iv) there is not a statistically significant relationship between asset tangibility and debt; v) the relationship between profitability and debt is negative and statistically significant; vi) the relationship between size and debt is positive and statistically significant; vii) the relationship between age and debt is negative and statistically significant; viii) the relationship between risk and debt is not statistically significant; and ix) the relationship between debt in the previous and current periods is positive and statistically significant, and so SMEs adjust their actual level of debt towards the optimal debt ratio.

\subsection{Discussions of the results}

The empirical results obtained with the LSDVC estimator by Bruno (2005) allow accept/ reject the validity of the previously formulated research hypotheses to determine if TradeOff and Pecking Order Theories are followed by SME in their capital structure decisions. 
Table 4. Debt determinants - LSDVC (2005) dynamic estimator

\begin{tabular}{|c|c|c|c|}
\hline \multirow[b]{2}{*}{$\begin{array}{l}\text { Independent } \\
\text { variables }\end{array}$} & \multicolumn{3}{|c|}{ Dependent variable: $\mathrm{LEV}_{\mathrm{i}, \mathrm{t}}$} \\
\hline & $\begin{array}{c}\text { LSDVC (2005) } \\
\text { Initial (AB) }\end{array}$ & $\begin{array}{l}\text { LSDVC (2005) } \\
\text { Initial (BB) }\end{array}$ & $\begin{array}{l}\text { LSDVC (2005) } \\
\text { Initial (AH) }\end{array}$ \\
\hline $\mathrm{LEV}_{i, t-1}$ & $\begin{array}{c}0.39652 * * * \\
(0.05092)\end{array}$ & $\begin{array}{c}0.45861 * * * \\
(0.05131)\end{array}$ & $\begin{array}{c}0.39538 * * * \\
(0.06157)\end{array}$ \\
\hline $\mathrm{ETR}_{i, t}$ & $\begin{array}{l}-0.00239 \\
(0.00578)\end{array}$ & $\begin{array}{l}-0.00169 \\
(0.00643)\end{array}$ & $\begin{array}{l}-0.00233 \\
(0.00177)\end{array}$ \\
\hline NDTS $_{i, t}$ & $\begin{array}{l}-0.48454 \\
(0.30216)\end{array}$ & $\begin{array}{l}-0.44431 \\
(0.32471)\end{array}$ & $\begin{array}{l}-0.48746 \\
(0.29965)\end{array}$ \\
\hline $\mathrm{GO}_{i, t}$ & $\begin{array}{l}-0.11367 \\
(0.36134)\end{array}$ & $\begin{array}{l}-0.08204 \\
(0.39038)\end{array}$ & $\begin{array}{l}-0.11379 \\
(0.36180)\end{array}$ \\
\hline $\mathrm{TANG}_{i, t}$ & $\begin{array}{l}-0.00837 \\
(0.08953)\end{array}$ & $\begin{array}{l}-0.00613 \\
(0.09818)\end{array}$ & $\begin{array}{l}-0.00621 \\
(0.09001)\end{array}$ \\
\hline $\mathrm{PROF}_{i, t}$ & $\begin{array}{c}-0.36028^{* * * *} \\
(0.10643)\end{array}$ & $\begin{array}{c}-0.39145^{* * * *} \\
(0.11499)\end{array}$ & $\begin{array}{c}-0.36053 * * * \\
(0.10532)\end{array}$ \\
\hline $\operatorname{SIZE}_{i, t}$ & $\begin{array}{c}0.05833^{* *} \\
(0.02410)\end{array}$ & $\begin{array}{c}0.06084 * * \\
(0.02572)\end{array}$ & $\begin{array}{c}0.05838^{* *} \\
(0.02386)\end{array}$ \\
\hline $\mathrm{AGE}_{i, t}$ & $\begin{array}{c}-0.08420^{* * *} \\
(0.03218)\end{array}$ & $\begin{array}{c}-0.07964 * * \\
(0.03529)\end{array}$ & $\begin{array}{c}-0.08399 * * * \\
(0.03199)\end{array}$ \\
\hline $\mathrm{EVOL}_{i, t}$ & $\begin{array}{c}0.00137 \\
(0.00090)\end{array}$ & $\begin{array}{c}0.00146 \\
(0.00099)\end{array}$ & $\begin{array}{c}0.00137 \\
(0.00090)\end{array}$ \\
\hline Firms & 53 & 53 & 53 \\
\hline Observations & 318 & 318 & 318 \\
\hline
\end{tabular}

Notes: 1 . Standardt Desviations in parenthesis. $2 . * * *$ Significant at $1 \%$ level; ** Significant at $5 \%$ level. 3. Initial (AB) - Correction of GMM dynamic estimator results; Initial (BB) - Correction of GMM System dynamic estimator results; Initial (AH) - Correction of Anderson-Hsiao dynamic estimator results. 4 . The estimates include time dummy variables but not show.

We identify a statistically insignificant relationship between effective tax rate and debt in SMEs, and so the previously formulated Hypothesis 1 cannot be validated. Debt tax shields seem not to motivate the SME managers/owners to contract debt. A statistically insignificant relationship is also found between non-debt tax shields and debt, therefore we cannot consider Hypothesis 2 as valid. These results indicate that the managers/owners of SMEs do not reduce the firm's level of debt due to the possibility of obtaining non-debt tax shields. The absence of statistically significant relationships between the independent variables of effective tax rate and non-debt tax shields suggests that the financing behaviour of SMEs does not agree with the forecasts of Trade-Off Theory. Michaelas et al. (1999) identified a negative relationship between effective tax rate and debt for SMEs in the United Kingdom, contrary to what is suggested by Trade-Off Theory. Sogorb-Mira (2005) for Spanish SMEs and Michaelas et al. (1999) for British SMEs found a negative relationship between non-debt tax shields and debt, which is according to the forecasts of Trade-Off Theory. 
The negative and statistically significant relationship between profitability and debt in SMEs does not allow us to accept Hypothesis 3, formulated with regard to Trade-Off Theory, but allows us validate Hypothesis 10 which predicts a negative relationship between the two variables in the context of Pecking Order Theory. This result indicates that SMEs prefer use internal financing rather than debt. Greater profitability allows greater possibility to retain profits, which are used to funding the firm's needs. These conclusions seem to agree with the assumptions of Pecking Order Theory, as according to which firms follow a hierarchy in choosing sources of finance, where preference is given to retained earnings, and only in case of their insufficiency, firms resort to debt. Van der Wijst and Thurik (1993), Chittenden et al. (1996), and Michaelas et al. (1999) identified an identical result for SMEs in the United Kingdom. Similar results were also found by Sogorb-Mira (2005) for Spanish SMEs, Psillaki and Daskalakis (2009) for Greek, French, and Italian SMEs, by Bhaird and Lucey (2010) for Irish SMEs, and La Rocca et al. (2011) for Italian SMEs.

The results obtained indicate a statistically insignificant relationship between growth opportunities and debt in SMEs, and so we cannot conclude that these firms follow the forecasts of Trade-Off Theory. It is therefore not possible to accept as valid the Hypothesis 4 formulated in the context of Trade-Off Theory. Nor it is possible to validate the previously formulated Hypothesis 11 in the context of Pecking Order Theory. Lopéz-Gracia and Sogorb-Mira (2008) obtain a negative relationship between growth opportunities and debt, which agrees with the forecasts of Trade-Off Theory. However, La Rocca et al. (2011) identify a positive relationship between growth opportunities and debt for Italian SMEs, corroborating the forecasts of Pecking Order Theory.

In the Hypothesis 5 is forecast a positive relationship between asset tangibility and debt in SMEs, reflecting the predictions of Trade-Off and Pecking Order Theories. The empirical results obtained indicate a statistically insignificant relationship between tangibility and debt, and so we cannot accept Hypotheses 5 and 12, formulated in the context of Trade-Off and Pecking Order Theories, respectively. The absence of a positive, statistically significant relationship between asset tangibility and debt suggests that tangible assets lose importance for SMEs to obtain debt. Hall et al. (2004) and SogorbMira (2005) find a negative relationship between asset tangibility and short-term debt. Probably, SMEs turn above all to short-term debt, and so guarantees associated with tangible assets are not required by creditors, justifying the absence of a positive relationship between tangible assets and debt obtained in the current study. The empirical results of various studies (Van der Wijst, Thurik 1993; Jordan et al.1998; Sogorb-Mira 2005; Chittenden et al. 1996, Michaelas et al. 1999; La Rocca et al. 2011) identified a positive relationship between asset tangibility and debt, showing the importance of tangible assets when SMEs resort to debt.

We identify a positive and statistically significant relationship between the variable of size and debt in SMEs, and so Hypothesis 6 is accepted, corroborating the forecasts of Trade-Off Theory. Greater size allows greater diversification of activities in SMEs, which, consequently, allows a reduction of the likelihood of bankruptcy, and so these 
firms increase their level of debt. Increased size, also, implies a greater possibility of obtaining profits, and therefore greater capacity to obtain debt for taking advantage of the debt tax shields. This fact could be relevant in explaining the positive relationship between size and debt in SMEs. These results agree with the assumptions of Trade-Off Theory. In the context of Pecking Order Theory, the previously formulated Hypothesis 13, about a significant relationship between size and debt in SMEs is also accepted, as the results show a positive and statistically significant relationship between these two variables. Increased size also means fewer problems of information asymmetry between owners/managers and creditors, allowing access to debt on more favourable terms. This fact may explain the positive relationship between size and level of debt in SMEs, in accordance with the forecasts of Pecking Order Theory. A positive relationship between size and debt was also identified by Van der Wijst and Thurik (1993), Chittenden et al. (1996) and Michaelas et al. (1999) for British SMEs, Sogorb-Mira (2005) for Spanish SMEs, Psillaki and Daskalakis (2009) for Greek, French, and Portuguese SMEs, Bhaird and Lucey (2010) for Irish SMEs, and by La Rocca et al. (2011) for Italian SMEs.

The negative and statistically significant relationship between age and debt in SMEs allows us to reject Hypothesis 7, in the context of Trade-Off Theory. This relationship allows us accept Hypothesis 14 in the context of Pecking Order Theory. Retention of profits tends to increase with greater firm's age, and so the need to resort to debt is less. Additionally, a negative relationship between age and debt was identified by Michaelas et al. (1999) for British SMEs, Bhaird and Lucey (2010) for Irish SMEs, and La Rocca et al. (2011) for Italian SMEs.

The positive and statistically insignificant relationship between risk and debt in SMEs does not allow the validation of Hypothesis 8 of this study. This result implies that we cannot claim that SMEs follow the assumptions defined by Trade-Off Theory. Just as in the current study, Van der Wijst and Thurik (1993) also identified a positive, but statistically insignificant relationship between risk and debt in British SMEs. Michaelas et al. (1999) also found evidence of a positive and statistically significant relationship between risk and debt in British SMEs. However, a negative and statistically significant relationship between those two variables was found by Sogorb-Mira (2005) for Spanish SMEs, Psillaki and Daskalakis (2009) for Greek SMEs, and Portuguese SMEs.

Table 5 presents a comparison of the results forecast by Trade-Off and Pecking Order Theories for the relationships between determinants and debt, and the results found for those relationships.

Regarding the rate of adjustment of actual debt towards the optimal debt ratio, irrespective of using the LSDVC dynamic estimator to correct the results of the GMM, GMM system, and Anderson and Hsiao dynamic estimators, SMEs are found to make a considerable adjustment towards the optimal debt ratio. Table 6 presents the values of the estimated adjustments.

The results suggest that firms adjust their actual debt level towards the optimal debt ratio, which agrees with the assumptions of Trade-Off Theory, allowing us to confirm the previously formulated Hypothesis 9 as valid. 
Table 5. Expected and verified relationships

\begin{tabular}{lccc}
\hline \multicolumn{4}{c}{ Dependent variable: LEV } \\
$\begin{array}{l}\text { Independent } \\
\text { variables }\end{array}$ & $\begin{array}{c}\text { Expected relationship }- \\
\text { Pecking Order Theory }\end{array}$ & $\begin{array}{c}\text { Expected relationship }- \\
\text { Trade-Off Theory }\end{array}$ & Verified relationship \\
\hline ETR & - & Positive & Not significant \\
\hline NTDS & - & Negative & Not significant \\
\hline GO & Positive & Negative & Not significant \\
\hline TANG & Positive & Positive & Not significant \\
\hline PROF & Negative & Positive & Negative \\
\hline SIZE & Positive or negative & Positive & Positive \\
\hline AGE & Negative & Positive & Negative \\
\hline EVOL & - & Negative & Not significant
\end{tabular}

Table 6. Debt adjustment speed

\begin{tabular}{cccc}
\hline & LSDVC (2005) I (AB) & LSDVC (2005) I (BB) & LSDVC (2005) I (AH) \\
\hline Adjustment speed & 0.60348 & 0.54139 & 0.60462 \\
\hline
\end{tabular}

Notes: Initial $(\mathrm{AB})$ - Correction of GMM dynamic estimator results; Initial (BB) - Correction of GMM System dynamic estimator results; Initial (AH) - Correction of Anderson-Hsiao dynamic estimator results.

The maximum adjustment value obtained is $\alpha=0.60462$ from application of the LSDCV (2005) (AH) dynamic estimator, and the minimum value obtained is $\alpha=0.54139$ from application of the LSDVC (2005) (BB) dynamic estimator. Although considering large firms quoted on the stock market, Kremp et al. (1999) obtain values of 0.53 and 0.28 for Germany, Shyam-Sunder and Myers (1999) 0.59 for the United States, De Miguel and Pindado (2001) 0.79 for Spain and Ozkan (2001) 0.57 for the United Kingdom. The figures obtained in this study are similar to those obtained in the above mentioned studies, which suggest that the adjustment costs are lower than the costs associated with an unbalanced capital structure for the firms. Therefore, Portuguese SMEs appear to make a relatively fast adjustment of their actual level of debt towards the optimal debt ratio. However, in the opposite, López-Gracia and Sogorb-Mira (2008) conclude that that high transaction costs are responsible for Spanish SMEs to adjust to their debt ratio very slowly, and that these firms seem to consider the costs of financial imbalance lower than the adjustment costs.

Summarizing, the negative and statistically significant relationships obtained in the current study between the independent variables of profitability and age, and the dependent variable of debt, are consistent with the assumptions of Pecking Order Theory. However, the positive and statistically significant relationship between size and debt allows us to validate the assumptions made by both Trade-Off and Pecking Order Theories. We also conclude that SMEs make a rapid adjustment of their actual debt towards the optimal debt ratio, suggesting that the costs of financial imbalance are greater than the costs 
that SMEs face in adjusting their actual debt towards the optimal level of debt. This result reinforces the conclusion, already referred to, that Trade-Off and Pecking Order Theories are not mutually exclusive. In general the results suggest that that these two theories are not mutually exclusive in explaining SME capital structure decisions.

\section{Conclusions, limitations and suggestions for future research}

Based on a sample of 53 SMEs in the interior region of Portugal for the period 19982005, using the LSDVC dynamic estimator by Bruno (2005), we seek if Trade-Off and Pecking Order theories are able to explain the capital structure decisions of these firms.

The results obtained indicate a negative relationship between profitability and debt, which suggest that SMEs prefer internal financing rather than external financing. As the most profitable firms are more able to retain profits over time, they become less dependent on debt. SME dependence on internal financing is also corroborated by the negative and statistically significant relationship between age and debt, suggesting that the greater is the firm's age, the greater is its possibility to retain profits and, consequently lesser is its need to resort to debt. The positive influence of size on recourse to debt indicates that greater firm size allows increased diversification of activities, which consequently reduces the probability of firm's bankruptcy.

The negative relationships between profitability and debt, and between age and debt, indicate that SMEs follow Pecking Order Theory in their capital structure decisions, showing the importance of internal financing for SMEs, particularly for the youngest ones. The positive relationship between size and debt can also be interpreted, according to the assumptions of Pecking Order Theory, since greater firm's size can lead to fewer problems of information asymmetry, and lower costs of deb for SME, allowing easier access to debt and on more favourable terms for those firms. Therefore, greater firm's size contributes to SMEs to obtain debt on more favourable terms.

The fact that tangible assets do not influence debt suggests that SMEs depend on shortterm debt, for which creditors do not require tangible assets as guarantees. So it seems that size and age are two relevant variables for SMEs obtaining credit, with tangible assets losing importance as potential guarantees. The statistically insignificant relationships between effective tax rate and debt, between non-debt tax shields and debt, and between risk and debt, suggest that SMEs do not give great importance to the debt tax shields and risk in their capital structure decisions, distancing themselves from the assumptions of the Trade-Off Theory.

The results also indicate that SMEs adjust, relatively quickly, their actual debt ratio towards the optimal debt ratio. This result suggests that the costs of financial imbalance are greater than the costs that SMEs bear, when adjusting their actual debt ratio towards the optimal debt ratio. Here, SMEs appear to adopt a financing behaviour in accordance with the forecasts of Trade-Off Theory.

In general, the results suggest that Pecking Order and Trade-Off Theories are not mutually exclusive in explaining the capital structure decisions of SMEs. The results obtained allow us to conclude that the capital structure decisions of SMEs can be explained in 
the light of the assumptions of both Trade-Off and Pecking Order Theories. On the one hand, SMEs make considerable adjustment of their actual debt towards the optimal level of debt, and size contributes to increased recourse to debt. These results corroborate the assumptions of Trade-Off Theory. On the other hand, more profitable, older SMEs turn less to debt, with increased recourse to debt as a function of their size. These results corroborate the forecasts of Pecking Order Theory.

Considering that Beira Interior is a relatively disadvantaged interior region of Portugal in the context of the national economy, where SMEs are especially important for increased employment and economic growth, we suggest that policy-makers should give effective support through favourable terms to these SMEs in obtaining debt. In that way, when internal financing is insufficient, young and small SMEs could turn to external financing on advantageous terms, allowing these firms to finance efficiently their activities.

A limitation of this study is the fact of analyzing only relationships between determinants and total debt. SMEs are very dependent on short-term debt, which may imply differences between the level of adjustment of short-term ratio and long term ratio towards the respective optimal debt ratios. Furthermore, it is desirable to separate the total ratio of debt into short and long-term debt ratios, for deeper understanding of the determinants of SME capital structure decisions.

Therefore, we suggest for future research to separate total debt into short and long-term debt, to analyse the differences between the level of adjustment of short-term debt and the level of adjustment of long-term debt towards the respective optimal levels; and, the relationships between usual determinants and short and long-term debt. The analysis of the SME short-term debt and long-term debt assumes particular importance due to the objective to identify the factors determinants in accessing short-term and long-term debt with the objective to verify if SME in the Beira Interior region face relevant difficulties in accessing long-term debt, being extremely dependent on short-term debt for funding their activities.

\section{Acknowledgements}

We are grateful for financial support of Portuguese FCT - Project PTDC/EGEGES/116004/2009.

\section{References}

Anderson, T.; Hsiao, C. 1981. Estimation of dynamic models with error components, Journal of the American Statistical Association 76: 598-606.

http://dx.doi.org/10.1080/01621459.1981.10477691

Ang, J. 1976. The intertemporal behavior of corporate debt policy, Journal of Financial and Quantitative Analysis 11: 555-566. http://dx.doi.org/10.2307/2330205

Ang, J. 1991. Small business uniqueness \& the theory of financial management, Journal of Small Business Finance 1: 1-13.

Ang, J.; Chua, J.; McConnell, J. 1982. The administrative cost of corporate bankruptcy: a note, The Journal of Finance 37: 219-226. http://dx.doi.org/10.1111/j.1540-6261.1982.tb01104.x 
Arellano, M.; Bond, S. 1991. Some tests of specification for panel data: Monte Carlo evidence and an application to employment equations, Review of Economic Studies 58: 277-297. http://dx.doi.org/10.2307/2297968

Baskin, J. 1989. An empirical investigation of the pecking order hypothesis, Financial Management 18: 26-35. http://dx.doi.org/10.2307/3665695

Bhaird, C.; Lucey, B. 2010. Determinants of capital structure in Irish SMEs, Small Business Economics 35: 357-375. http://dx.doi.org/10.1007/s11187-008-9162-6

Blundell, M.; Bond, S. 1998. Initial conditions and moment restrictions in dynamic panel data models, Journal of Econometrics 87: 115-143. http://dx.doi.org/10.1016/S0304-4076(98)00009-8

Bradley, M.; Jarrell, G.; Kim, E. 1984. On the existence of a capital structure: theory and evidence, The Journal of Finance 39: 857-878. http://dx.doi.org/10.1111/j.1540-6261.1984.tb03680.x

Berger, A.; Udell, G. 1998. The economics of small business finance: the roles of private equity and debt markets in the financial growth cycle, Journal of Banking and Finance 22: 613-673. http://dx.doi.org/10.1016/S0378-4266(98)00038-7

Berggren, B.; Olofsson, C.; Silver, L. 2000. Control aversion and the search for external financing in Swedish SMEs, Small Business Economics 15: 233-242.

http://dx.doi.org/10.1023/A:1008153428618

Bruno, G. 2005. Approximating the bias of LSDV estimator for dynamic unbalanced panel data models, Economic Letters 87: 361-366. http://dx.doi.org/10.1016/j.econlet.2005.01.005

Cassar, G.; Holmes, S. 2003. Capital structure and financing of SMEs: Australian evidence, Accounting and Finance 43: 123-147. http://dx.doi.org/10.1111/1467-629X.t01-1-00085

Chittenden, F.; Hall, G.; Hutchinson, P. 1996. Small firm growth access to capital markets and financial structure: review of issues and an empirical investigation, Small Business Economics 8: 59-67. http://dx.doi.org/10.1007/BF00391976

De Miguel, A.; Pindado, J. 2001. Determinants of capital structure: new evidence from Spanish panel data, Journal of Corporate Finance 7: 77-99.

http://dx.doi.org/10.1016/S0929-1199(00)00020-1

DeAngelo, H.; Masulis, R. 1980. Capital structure under corporate and personal taxation, Journal of Financial Economics 8: 3-29. http://dx.doi.org/10.1016/0304-405X(80)90019-7

Degryse, H.; Goeij, P.; Kappert, P. 2010. The impact of firm and industry characteristics on small firms capital structure, Small Business Economics 38: 431-447.

http://dx.doi.org/10.1007/s11187-010-9281-8

Ezeoha, A. 2008. Firm size and corporate financial leverage choice in a developing economy, The Journal of Risk Finance 9: 351-364. http://dx.doi.org/10.1108/15265940810895016

Fama, E.; French, K. 2002. Testing trade-off and pecking order predictions about dividends and debt, The Review of Financial Studies 15: 1-33. http://dx.doi.org/10.1093/rfs/15.1.1

González, V.; González, F. 2012. Firm size and capital structure: evidence using dynamic panel data, Applied Economics 44: 4745-4754. http://dx.doi.org/10.1080/00036846.2011.595690

Gujarati, D.; Porter, D. 2010. Essentials of econometrics. $4^{\text {th }}$ ed. New York: McGraw - Hill International.

Hall, G.; Hutchinson, P.; Michaelas, N. 2000. Industry effects on the determinants of unquoted SMEs capital structure, International Journal of Economics of Business 7: 297-312.

http://dx.doi.org/10.1080/13571510050197203

Hall, G.; Hutchinson, J.; Michaelas, N. 2004. Determinants of the capital structure of European SMEs, Journal of Business \& Accounting 31: 711-728.

http://dx.doi.org/10.1111/j.0306-686X.2004.00554.x

Haugen, R.; Senbet, L. 1986. Corporate finance and taxes: a review, Financial Management 15: 5-21. http://dx.doi.org/10.2307/3664840 
Hovakimian, A.; Opler, T.; Titman, S. 2001. The debt-equity choice, Journal of Financial and Quantitative Analysis 36: 1-24. http://dx.doi.org/10.2307/2676195

Ibbotson, R.; Sindelar, J.; Ritter, J. 2001. Initial public offerings, in D. H. J. Chew (Ed.). The new corporate finance. Where theory meets practice. 3rd ed. New York: McGraw Hill-Irwin.

Jalilvand, A.; Harris, R. 1984. Corporate behavior in adjusting to capital structure and dividend targets: an econometric study, The Journal of Finance 39: 127-145.

http://dx.doi.org/10.1111/j.1540-6261.1984.tb03864.x

Jensen, M.; Meckling, W. 1976. Theory of the firm: managerial behavior, agency costs and ownership structure, Journal of Financial Economics 3: 305-360. http://dx.doi.org/10.1016/0304405X(76)90026-X

Jordan, J.; Lowe, J.; Taylor, P. 1998. Strategy and financial policy in U.K. small firms, Journal of Business Finance and Accounting 25: 1-27. http://dx.doi.org/10.1111/1468-5957.00176

Kim, E. 1978. A Mean-variance theory of capital structure and corporate debt capacity, The Journal of Finance 33: 45-63. http://dx.doi.org/10.1111/j.1540-6261.1978.tb03388.x

Kraus, A.; Litzenberger, R. 1973. A state-preference model of financial leverage, The Journal of Finance 28: 911-922. http://dx.doi.org/10.1111/j.1540-6261.1973.tb01415.x

Kremp, E.; Stöss, E.; Gerdesmeier, D. 1999. Estimation of a debt function: evidence form French and German firm panel data, in A. Sauve, M. Scheuer, H. Friderichs (Eds.). Corporate finance in Germany and France. Frankfurt am Main: Deutsche Bundesbank, 140-191.

La Rocca, M.; La Rocca, T.; Cariola, A. 2011. Capital structure decisions during a firm's life cycle, Small Business Economics 37: 107-130. http://dx.doi.org/10.1007/s11187-009-9229-z

Lev, B.; Peckelman, D. 1975. A multiperiod adjustment model for the firm's capital structure, The Journal of Finance 30: 75-92. http://dx.doi.org/10.1111/j.1540-6261.1975.tb03161.x

López-Gracia, J.; Aybar-Arias, C. 2000. An empirical approach to the financial behaviour of small and medium sized companies, Small Business Economics 14: 55-63.

http://dx.doi.org/10.1023/A:1008139518709

López-Gracia, J.; Sánchez-Andújar, S. 2007. Financial structure of the family business: evidence from a group of small Spanish firms, Family Business Review 20: 269-287.

http://dx.doi.org/10.1111/j.1741-6248.2007.00094.x

Lopéz-Gracia, J; Sogorb-Mira, F. 2008. Testing trade-off and pecking order theories financing SMEs, Small Business Economics 38: 117-136. http://dx.doi.org/10.1007/s11187-007-9088-4

Mackie-Mason, J. 1990. Do taxes affect corporate financing decisions?, The Journal of Finance 45:1471-1493. http://dx.doi.org/10.1111/j.1540-6261.1990.tb03724.x

Marsh, P. 1982. The choice between equity and debt: an empirical study, The Journal of Finance 37: 121-144. http://dx.doi.org/10.1111/j.1540-6261.1982.tb01099.x

McMahon, R.; Holmes, S.; Hutchinson, P.; Forsaith, M. 1993. Small enterprise financial management - theory and practice. Australia: Harcourt Brace \& Company.

Michaelas, N.; Chittenden, F.; Poutziouris, P. 1999. Financial policy and capital structure choice in U.K. SMEs: empirical evidence from company panel data, Small Business Economics 12: 113-130. http://dx.doi.org/10.1023/A:1008010724051

Modigliani, F.; Miller, M. 1958. The cost of capital, corporation finance and the theory of investment, The American Economic Review 48: 291-297.

Modigliani, F.; Miller, M. 1963. Corporate income taxes and the cost of capital: a correction, The American Economic Review 53: 433-443.

Myers, S. 1977. Determinants of corporate borrowing, Journal of Financial Economics 5: 147175. http://dx.doi.org/10.1016/0304-405X(77)90015-0

Myers, S. 1984. The capital structure puzzle, The Journal of Finance 39: 575-592.

http://dx.doi.org/10.2307/2327916 
Myers, S.; Majluf, N. 1984. Corporate financing and investment decisions when firms have information that investors do not have, Journal of Financial Economics 13: 187-221.

http://dx.doi.org/10.1016/0304-405X(84)90023-0

Ou, C.; Haynes, G. W. 2006. Acquisition of additional equity capital by small firms - findings from the national survey of small business finances, Small Business Economics 27: 157-168. http://dx.doi.org/10.1007/s11187-006-0009-8

Ozkan, A. 2001. Determinants of capital structure and adjustment to long run target: evidence from UK company panel data, Journal of Business Finance \& Accounting 28: 175-198.

http://dx.doi.org/10.1111/1468-5957.00370

Psillaki, M.; Daskalakis, N. 2009. Are the determinants of capital structure country or firm specific?, Small Business Economics 3: 319-333. http://dx.doi.org/10.1007/s11187-008-9103-4

Ramalho, J.; Silva, J. 2009. A two-part fractional regression model for the financial leverage decisions of micro, small, medium and large firms, Quantitative Finance 9: 621-636.

http://dx.doi.org/10.1080/14697680802448777

Ross, G. 1977. The determination of financial structure: the incentive signaling approach, Bell Journal of Economics \& Management Science 8: 23-44.

Scherr, F.; Hulburt, H. 2001. The debt maturity structure of small firms, Financial Management Spring: 85-111. http://dx.doi.org/10.2307/3666392

Scott, J. 1977. Bankruptcy, secured debt, and capital structure, The Journal of Finance 32: 1-19. http://dx.doi.org/10.1111/j.1540-6261.1977.tb03237.x

Serrasqueiro, Z.; Maçãs Nunes, P. 2012. Is age a determinant of financing decisions of SMEs? Empirical evidence using panel data models, Entrepreneurship Theory \& Practice 36: 611-887. http://dx.doi.org/10.1111/j.1540-6520.2010.00433.x

Smith, C.; Warner, J. 1979. On financial contracting: an analysis of bond covenants, Journal of Financial Economics 7: 117-161. http://dx.doi.org/10.1016/0304-405X(79)90011-4

Smith, C.; Stulz, R. 1985. The determinants of firms' hedging policies, Journal of Financial and Quantitative Analysis 20: 391-405. http://dx.doi.org/10.2307/2330757

Sogorb-Mira, F. 2001. On capital structure in the small and medium enterprises: the Spanish case, SSRN [online], [cited 31 May 2011. Available from Internet: http://ssrn.com/abstract=277090. http://dx.doi.org/10.2139/ssrn.277090

Sogorb-Mira, F. 2005. How SME uniqueness affects capital structure: evidence from a 19941998 Spanish data panel, Small Business Economics 25: 447-457.

http://dx.doi.org/10.1007/s11187-004-6486-8

Shyam-Sunder, L.; Myers, S. 1999. Testing static trade-off against pecking order models of capital structure, Journal of Financial Economics 51: 219-244.

http://dx.doi.org/10.1016/S0304-405X(98)00051-8

Taggart, R. 1977. A model of corporate financing decisions, The Journal of Finance 32: 14671484. http://dx.doi.org/10.1111/j.1540-6261.1977.tb03348.x

Titman, S.; Wessels, R. 1988. The determinants of capital structure choice, The Journal of Finance 43: 1-19. http://dx.doi.org/10.1111/j.1540-6261.1988.tb02585.x

Van der Wijst, D.; Thurik, R. 1993. Determinants of small firm debt ratios: an analysis of retail panel data, Small Business Economics 5: 55-65. http://dx.doi.org/10.1007/BF01539318

Viviani, J. 2008. Capital structure determinants: an empirical study of French companies in the wine industry, International Journal of Wine Business Research 20: 171-194.

http://dx.doi.org/10.1108/17511060810883786

Wald, J. 1999. How firm characteristics affect capital structure: an international comparison, The Journal of Financial Research 22: 61-187.

Warner, J. 1977. Bankruptcy costs: some evidence, The Journal of Finance 32: 337-348.

http://dx.doi.org/10.2307/2326766 


\section{APPENDIX}

Table A1. Correlation matrix

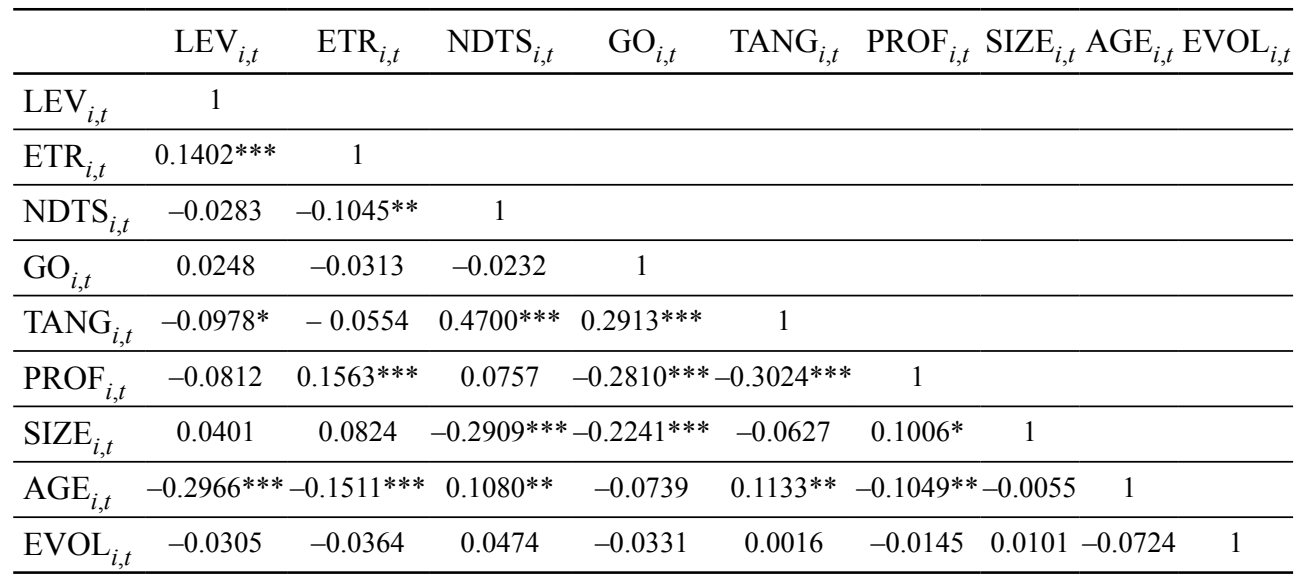

Notes: $1 .{ }^{* *}$ Significant at $1 \%$ level; ** Significant at $5 \%$ level; $*$ Significant at $10 \%$ level.

Zélia SERRASQUEIRO, PhD in Management, Associate Professor at the Department of Management and Economics to Beira Interior University and Researcher in CEFAGE-UE (Center for Advanced Studies in Management and Economics). The research interests are Corporate Finance and Entrepreneurial Finance. Zélia Serrasqueiro is the author of articles in various journals: Journal of Business Economics and Management, Entrepreneurship Theory \& Practice, Research Policy, Journal of Evolutionary Economics, Small Business Economics, Industrial and Corporate Change, Journal of Business Research, Journal of Service Management, Applied Economics, Applied Economics Letters, Applied Financial Economics Letters, the Services Industries Journal, Management Research Review, Social Responsibility Journal, Review of Accounting and Finance, and other journals.

Ana CAetano, Master in Management in Beira Interior University. The research interests are Corporate Finance and Entrepreneurial Finance. 